\title{
POLIGAMI DAN KETIDAKADILAN GENDER DALAM UNDANG- UNDANG PERKAWINAN DI INDONESIA
}

\author{
Nur Kholis ${ }^{1}$, Jumaiyah ${ }^{2}$, Wahidullah ${ }^{3}$ \\ Universitas Islam Nahdlatul Ulama (Unisnu), Jepara \\ e-mail: ${ }^{1}$ nurkholis@unisnu.ac.id; ${ }^{2}$ mayawahidah@unisnu.ac.id; \\ 33ahidullah@unisnu.ac.id
}

\begin{abstract}
The article 4 clause 2 in the Act Number 1 Year 1974, mentioned that discrimination against women (wife) potentially in increasing the divorce rates. It can be minimized by creating a gender-based mindset, that will be the object of this research. This research will use qualitative methods with normative juridical approach. This research found that: firstly, that the Act Number 1 Year 1974 and its derivative laws such as Compilation of Islamic Law (KHI), has not reach yet the Pancasila values and also justice and humanity as the main mission of law. Secondly, the political configuration in the drafting of laws and "black and white" in understanding of religious texts are contribute to creating injustice. Thirdly, the justice is one of the goals of the law, so discrimination must be eliminated. This research provides a recommendation that polygamy in article 4 clause 2 in the Act Number 1 Year 1974 must be removed, and become the principle of monogamy absolutely.
\end{abstract}

[]

Diskriminasi terhadap perempuan (Isteri), sebagaimana tertuang pada Pasal 4 ayat 2 UU No. 1 Tahun 1974, berpotensi menciptakan tingginya angka perceraian. Meminimalisasi hal tersebut dengan membangun pemikiran berbasis keadilan gender merupakan tujuan dalam penelitian ini. Adapun metode yang dipilih adalah kualitatif dengan pendekatan yuridis-normatif. Hasil penelitian yang ditemukan; Pertama, bahwa UU No. 1 Tahun 1974 beserta perundang-undangan turunannya seperti KHI, masih jauh dari nilai-nilai Pancasila dan misi utama hukum; yaitu nilai keadilan dan kemanusiaan. Kedua, konfigurasi politik dalam produksi UU Perkawinan dan pemahaman teks agama yang "hitam-putih" adalah kontributor terciptanya ketidakadilan. Ketiga, salah satu tujuan hukum adalah keadilan, maka bentuk-bentuk diskriminasi harus dihapuskan. Artikel ini merekomendasikan penghapusan poligami dalam pasal 4 ayat 2 UU No.1 Tahun 1974, dan menjadikan monogami bersifat mutlak.

Keywords: marriage laws; gender inequity; polygamy 
Nur Kholis, Jumaiyah, Wahidullah

\section{Pendahuluan}

Undang-Undang Republik Indonesia No. 1 Tahun 1974 tentang perkawinan yang telah diundangkan pada tanggal 2 Januari 1974 (dan berlaku secara efektif mulai tanggal 1 Oktober 1975) merupakan ijitihad hukum bangsa Indonesia dalam menata keluarga Indonesia. ${ }^{1}$ Keberadaan hukum perkawinan ini juga ditegaskan sebagai aktualisasi nilai-nilai Pancasila, ${ }^{2}$ serta sebagai kebutuhan yang mutlak adanya bagi negara dan bangsa Indonesia. ${ }^{3}$

Kata "mutlak" dalam memori penjelasan undang-undang tersebut memberikan penjelasan bahwa sebagai bangsa dan negara yang berdaulat (merdeka), sudah seharusnya menata secara mandiri untuk warga negaranya dan sistem hukumnya sesuai dengan prinsip-prinsip dan pegangan yang berlaku bagi semua golongan dalam masyarakat Indonesia. Dengan kata lain, Pancasila sebagai falsafah hidup bangsa Indonesia harus menjadi norma hukum negara - termasuk khususnya terkait hukum perkawinan-dalam melakukan pembinaan hukum secara nasional dengan berbagai aspek; yaitu meliputi subtansi, struktur maupun kultur.

Bagi masyarakat Indonesia, perkawinan sangat terkait dengan keyakinan dan norma agama. Sekiranya Pasal 1 dari UU No. 1 Tahun 1974 memang telah sejalan dengan falsafah Pancasila. Pasal tersebut menyebutkan:

"Perkawinan ialah ikatan lahir batin antara seorang pria dengan seorang wanita sebagai suami istri dengan tujuan membentuk keluarga (rumah tangga) yang bahagia dan kekal berdasarkan Ketuhanan Yang Maha Esa."

Dari pasal tersebut dapat dipahami bahwa perkawinan di Indonesia merupakan salah satu ritus atau praktik keagamaan, baik dalam prosesi perkawinan maupun membinanya dikategorikan sebagai ibadah sosial. Konstruksi hukum yang dibangun dalam Pasal 1 tentang perkawinan ini dapat memberikan kesan bahwa dengan ibadah/ritual berbentuk perkawinan maka

\footnotetext{
1Sesuai Pasal 66 Undang-Undang No. 1 Tahun 1974, Undang-undang tersebut menjadi pengganti dan sekaligus menyatakan tidak berlakunya perundangan-undangan peninggalan Belanda yaitu KUH Perdata (BW) maupun peraturan lainnya tentang perkawinan. Lihat Soemiyati, Hukum Perkawinan Islam dan Undang-Undang Perkawinan (Yogyakarta: Liberty, 2007), h. 2.

2Sebagaimana dinyatakan dalam bagian “Menimbang” pada UU No. 1 Tahun 1974.

3Sebagaimana dinyatakan dalam "Penjelasan Umum” No. 1 pada UU No. 1 Tahun 1974.
} 
kedua belah pihak dapat mencapai kehidupan yang kekal dan bahagia berdasarkan orientasi tertinggi agama, yakni Ketuhanan Yang Maha Esa. Perkawinan tidak hanya orientasi sekularisme semata, melainkan juga orienttasi asketisme dapat dirasakan kehadirannya.

Hal ini berbeda dengan konsep perkawinan KUH Perdata (Burgerlijk Wetboek), khususnya sebagaimana pada ketentuan Pasal 26 KUHPerdata (Burgerlijk Wetboek) yang memandang perkawinan hanya sebatas hubungan keperdataan belaka. ${ }^{4}$ Misalnya buku I titel 5 Pasal 30 NBW berbunyi "De Wet beschouwt het huwelijk alleen in zijn burgerlijke betrekkingen" (Undang-undang memandang perkawinan hanya sebagai hubungan keperdataan semata). ${ }^{5}$ Bahkan, sebagaimana dinyatakan Djaja S. Meliala, bahwa hidup bersama di Negara Belanda tanpa nikahpun dapat dicatatkan di hadapan pegawai pencatat. 6

Bukanlah sesuatu yang asing jika dikatakan bahwa hukum selalu hadir dengan sarat muatan kepentingan.7 Sebagaimana pernyataan Sinzheimer, bahwa hukum tidak lahir dan bergerak dari ruang yang hampa dan berhadapan dengan hal-hal yang abstrak, melainkan ia selalu berada dalam suatu tatanan sosial tertentu dan manusia-manusia yang hidup. ${ }^{8}$ Maka dapat diperkirakan kiranya bahwa kehadiran UU No. 1 Tahun 1974 tidak terlepas dari muatan kepentingan, baik kepentingan individu maupun kelompok. Jika memang benar demikian, melihat proses dinamisasi produksi perundang-undangan, dapat dikatakan bahwa setiap produk hukum telah "cacat" sejak lahir.

Mencermati Pasal 4 UU No. 1 Tahun 1974 tentang ketentuan pemberian izin oleh Pengadilan terhadap suami untuk beristri lebih dari seorang (poligami), rasanya dapat ditemui adanya aroma ketidakadilan di dalamnya. Pasal tersebut menyatakan:

4R. Subekti dan R.Tjitrosudibio, Kitab Undang-Undang Hukum Perdata, Edisi Revisi, Burgerlijk Wetboek (Jakarta: Pradnya Paramita, 1995), h. 8.

${ }^{5}$ Djaja S. Meliala, Hukum Perdata dalam perspektif BW (Bandung: Nuansa Aulia, 2013), h. 49.

${ }^{6}$ Djaja S. Meliala, Hukum Perdata dalam perspektif BW, h. 49.

7Sudikno Mertokusumo, Mengenal Hukum (Yogyakarta: Universitas Atmajaya, 2010), h. 2. 3.

8Esmi Warasih, Pranata Hukum: Sebuah Telaah Sosiologis (Semarang: Suryadaru Utama, 2005), h. 
"Pengadilan dimaksud pada ayat (1) pasal ini hanya memberikan izin kepada seorang suami yang akan beristri lebih dari seorang apabila:

(a) istri tidak dapat menjalankan kewajibannya sebagai istri;

(b) istri mendapat cacat badan atau penyakit yang tidak dapat disembuhkan;

(c) istri tidak dapat melahirkan keturunan."

Artikel ini merupakan hasil penelitian kualitatif terhadap dokumen Undang-undang Perkawinan No.1 Tahun 1974. Adapun pendekatan yang digunakan adalah pendekatan yuridis-normatif untuk menganalisis konteks ketidakadilan gender dalam Undang-Undang No. 1 Tahun 1974 tentang Perkawinan, utamanya pasal 4 yang memuat ketentuan poligami.

\section{Ketidakadilan Gender dan Konfigurasi Politik UU No. 1 Tahun 1974 tentang Perkawinan}

Untuk menjawab permasalahan ketidakadilan dalam Undang-Undang Perkawinan di Indonesia, tulisan ini menggunakan analisis teori feminisme. Sebagaimana dijelaskan Akhyar Yusuf Lubis, feminisme adalah paradigma atau sebagai kajian sekaligus metodologi yang bertujuan untuk mengungkap realitas sosial, budaya, politik dan sebagainya yang terdapat ketimpangan gender, relasi yang timpang antara laki-laki dan perempuan, ketertindasan perempuan, stereotipe yang tidak benar yang dilekatkan kepada kaum perempuan. ${ }^{9}$ Bukan hanya sebagai kajian ataupun metodologi, feminisme juga sebagai gerakan, ia memiliki tujuan (kepentingan). Ada beberapa tujuan yang hendak dicapai dalam gerakan feminisme, yaitu: 1) Menyediakan informasi dan analisis mengenai kehidupan kaum perempuan; 2) Mengupayakan perubahan serta menghilangkan ketidaksetaraan gender dan subordinasi kaum perempuan; 3) Menjadikan kritik terhadap ilmu yang telah ada; 4) Mem-

${ }^{9}$ Akhyar Yusuf Lubis, Pemikiran Kritis Kontemporer: Dari Teori Kritis Hingga Multikulturalisme (Jakarta: Rajawali Press, 2015), h. 95. Feminisme adalah gerakan yang memperjuangkan kesetaraan gender. Kajian feminisme membedakan antara kategari seks dan gender. Seks adalah perbedaan alamiah antara laki-laki dan perempuan. Sedangkan gender perbedaan tidak alamiah melalui proses sosial dan kultur panjang, yang cenderung mensubordinasikan dan menindas kaum perempuan. Mustafied (ed.), Kontekstualisasi Turast; Telaah Regresif dan Progresif (Surabaya: De-aly, 2009), h. 8283. Sementara Nasarudin Umar menyatakan bahwa gender adalah laki-laki dan perempuan dari sudut non-biologis. Nasarudin Umar, Argumentasi Kesetaraan Gender Perspektif al-Qur'an (Jakarta: Paramadina, 1999), h. 35. 
perlihatkan perempuan sebagai perspektif mengenai ilmu pengetahuan yang sebelumnya belum terlibat. ${ }^{10}$

Mansour Fakih,11 mendeskripskan perbedaan gender tersebut dengan menyatakan:

"Sebenarnya perbedaan gender bukanlah menjadi masalah, sepanjang tidak melahirkan ketidakadilan gender, persoalannya perbedaan gender telah melahirkan berbagai ketidakadilan..."

Ketidakadilan gender yang dimaksud termanifestasikan dalam beragam bentuk. Pertama, terjadi marginalisasi (terutama pemiskinan ekonomi) terhadap perempuan. Kedua, terjadinya subordinasi pada salah satu jenis kelamin, umumnya kepada kaum perempuan. Ketiga, pelabelan negatif (strereotype) terhadap jenis kelamin tertentu, yang berakibat diskriminasi dan berujung ketidakadilan. Keempat, kekerasan terhadap jenis kelamin tertentu, umumnya terhadap perempuan. Kelima, beban kerja lebih panjang dan lebih banyak (double burden). Semua manifes ketidakadilan gender di atas saling terkait dan tersosialisasi dengan kuat sehingga menjadi konstruksi sosial dan akhirnya dipahami menjadi kodrat.12

Berangkat dari ketidakadilan gender yang termanifestasikan dalam berbagai tindakan, maka tatanan hukum pun terbuka menjadi ruang ketidakadilan. Salah satunya adalah Undang-Undang Perkawinan. Seperti dinyatakan Mahfud MD,13 bahwa produk hukum sangat dipengaruhi oleh konfigurasi politik yang ada, karena ia memiliki energi lebih dibanding hukum itu sendiri. Dengan demikian, apabila konfigurasi politik berpola otoriter maka ia akan

\footnotetext{
${ }^{10}$ Gerakan ini dimulai sekitar tahun 1830-1920, sebagai gelombang Pertama, tokohnya yaitu Mary Wallstonescraft, Sojourner Truth, Elizabeth Candy Stanton dan Juane Ines. Gerakan pada gelombang pertama titik tekannya pada penuntutan pada hak suara dan perjuangan sipil bagi perempuan, dengan latar belakang faktor ketidakadilan dan ketertindasan serta upaya mengubah situasi kondisi. Gelombang kedua, dimulai awal 1920 s.d 1960/1970, ia merupakan kelanjutan yang pertama, dengan upaya menghasilkan teori-teori baru, berdasarkan pengalaman dan harapan kaum perempuan dan juga dipengaruhi oleh teori kritis. Tokohnya antara lain Simon de Baouvoir, Betty Friedan, Kate Millet dan Germaine Greer. Adapun feminisme gelombang ketiga dimulai pasca 1960an/1970-an dengan pengaruh kuat dari teori postmodernisme dan poststrukturalisme. Tokoh gelombang ketiga yaitu: Helen Cixous, Luce Iragaray dan Yulia Kristeva. Lihat Akhyar Yusuf Lubis, Pemikiran Kritis Kontemporer, h. 96-100.

11Mansour Fakih, Analisis Gender dan Trasformasi Sosial (Yogyakarta: Pustaka Pelajar, 2013), h. 12.

12 Ibid., h. 71-76.

13Mahfud MD, Politik Hukum di Indonesia (Jakarta: Raja Grafindo, 2009), h. 20-22.
} 
melahirkan produk hukum berwatak represif. Demikian halnya jika konfigurasi politiknya bias gender, maka ketidakadilan gender sangat potensial tercipta. Variabel dominasi laki-laki yang begitu kuat dan ditambah pemahaman teks keberagamaan yang dipengaruhi pola diskriminatif dan berketidakadilan gender sangat menentukan produk hukum yang kemungkinan besar juga berwatak tidak adil gender.

Kesejarahan proses penyusunan hingga penetapan Undang-Undang Perkawinan yang memakan waktu lama, tidak bisa dilepaskan dari dinamika perpolitikan di negeri ini. Ideologi pembangunan era Orde Baru ${ }^{14}$ menjadi landasan pikir dan gerak untuk menciptakan stabilitas keamanan, ekonomi dan politik, dan akhirnya diterima masyarakat sebagai kewajiban memberi dukungan pada setiap aspek hukum. Sebagaimana disampaikan Mochtar Kusuma Atmaja, ketika menjabat Menteri Kehakiman, hukum dapat berfungsi sebagai sarana pembangunan (law as a tool of development), artinya hukum difungsikan sebagai alat atau sarana untuk mengatur pembangunan. ${ }^{15}$ Teori ini mengacu pada teori Roscou Pound ${ }^{16}$ yang menjelaskan bahwa hukum memiliki tugas sebagai kontrol sosial dan sebagai pengubah masyarakat (law as a tool of social engineering). Alat pengubah masyarakat yang dimaksud oleh Pound adalah suatu proses mekanik. Hal itu terlihat dengan adanya perkembangan industri dan traksaksi-transaksi bisnis yang memperkenalkan nilai dan norma baru, yang menjadi "pengubah" di tangan hakim melalui interpretasi ketika mengadili kasus secara seimbang (balance). ${ }^{17}$

Undang-Undang Nomor 1 Tahun 1974 tentang Perkawinan merupakan bagian penting dalam pembangunan untuk diwujudkan oleh Pemerintah

\footnotetext{
${ }^{14}$ Suriansyah Murhaini, Hukum dan Sejarah Hukum: Pengantar Singkat Memahami Sejarah Hukum Indonesia (Yogyakarta: LaksBang Pressindo, 2016), h. 146.

15Romli Atmasasmita, Teori Hukum Integratif Rekonstruksi terhadap Teori Hukum Pembangunan dan Teori Hukum Progresif(Yogyakarta: Genta Publishing, 2014), h. 59-60.

${ }^{16}$ Soerjono Soekanto, Pokok-Pokok Sosiologi Hukum (Jakarta: Rajawali Press, 1987), h. 35-38. Dijelaskan bahwa Roscoe Pound (1870-1964) yang mempopulerkan Amirika Serikat tentang aliran Sociological Jurisprudence. Aliran ini dipelopori oleh Eugen Ehrlich (1826-1922) melalui karyanya Fundamental Princiles of the Sosiologi of Law, yang menyatakan bahwa, "tata tertib dalam masyarakat didasarkan pada peraturan-peraturan yang dipaksakan oleh negara". Di samping itu Pound juga dipengaruhi oleh pemikiran social utilitarianisme Rudolph von Ihering (1818-1892) yang menganggap bahwa hukum merupakan alat bagi masyarakat untuk mencapai tujuannya.

17Zainuddin Ali, Sosiologi Hukum (Jakarta: Media Grafika, 2017), h. 24.
} 
Soeharto; di samping GBHN 1973. Dalam pidato kenegaraan pada tanggal 16 Agustus 1973, Soeharto menyatakan:

"Dalam membina keluarga yang berbahagia sangatlah perlu usaha yang sungguh-sungguh untuk meletakkan perkawinan sebagai ikatan suami istri atau calon suami istri dalam kedudukannya yang semestinya dan suci, seperti yang diajarkan oleh agama yang kita anut masing-masing dalam negara yang berdasarkan Pancasila ini. Karena itu, sudah seharusnya apabila negara memberi perlindungan yang selayaknya pada keselamatan perkawinan. Perlindungan yang diberikan kepada suami atau istri terhadap tujuan-tujuan yang menyimpang dari keluhuran perkawinan."18

Undang-Undang Perkawinan yang digadang-gadang oleh Pemerintah Soeharto ternyata tidak semulus sebagaimana yang diharapkan. Sebulan sebelum pengajuannya menjadi undang-undang, muncul reaksi keras dari berbagai lapisan masyarakat Muslim berupa pernyataan penolakan atas RUU tersebut. Banyak ulama, baik dari kalangan tradisonal maupun modernis, dari Aceh sampai Jawa Timur, menolak RUU tersebut. Penolakan itu disampaikan melalui beberapa media; khutbah di masjid-masjid, ceramah, pengajian, tulisan di koran, demonstrasi-demonstrasi, dan surat pernyataan organisasi kemasyarakatan Islam. ${ }^{19}$

Isu "kristenisasi Indonesia" menjadi latar belakang penolakan terhadap RUU tersebut. Di samping "isu akidah" penolakan juga dipicu oleh iklim politik pada saat itu dimana kekalahan partai politik Islam dalam Pemilu 1971 dirasakan sebagai gejala depolitisasi Islam. Kecurigaan atas isu tentang kristenisasi sudah mencuat sejak tahun 1970-an terutama ketika dipicu pemberitaan media surat kabar di Timur Tengah yang pada waktu itu memberitakan bahwa berjuta-juta umat Islam di Indonesia masuk Kristen. ${ }^{20}$

Namun di saat bersamaan, komposisi dukungan terhadap "nasib perempuan" di dalam parlemen sangat minim. Bahkan pada masa itu boleh jadi keberpihakan terhadap perempuan dapat dimaknai sebagai bentuk pertentangan terhadap ajaran agama (Islam). Para pemikir politik memang banyak yang

\footnotetext{
18Weinata Sairin dan J.M Pattiasina, Pelaksanaan Undang-Undang Perkawinan dalam Perspektif Kristen (Jakarta: Gunung Mulia, 1996), h. 200.

${ }_{19}^{19}$ Abdul Aziz Thaba, Islam dan Negara dalam Politik Orde Baru (1966-1994), (Jakarta: Gema Insani Press, 1996), h. 256.

${ }^{20}$ Abdul Aziz Thaba, Islam dan Negara, h. 256.
} 
menulis tentang masalah perempuan, hanya saja dengan perspektif yang memberikan legitimasi peran domestik perempuan, memberikan justifikasi terhadap subordinasi serta ketidaktampakan perempuan di ranah publik (public invisibility). ${ }^{21}$ Politik secara konsisten dapat dikatakan hanya ranah milik laki-laki (male preserve). Hal yang demikian nyata-nyata memberikan legitimasi terhadap peminggiran perempuan; dengan alasan ketidakmampuan perempuan, atau tidak adanya kapasitas yang dimiliki oleh perempuan di bidang politik karena kodratnya sebagai istri dan ibu rumah tangga. ${ }^{22}$

Selanjutnya dalam konfigurasi peta kekuatan politik pada waktu itu, terhadap produk hukum khususnya Undang-Undang Perkawinan, bahwa terdapat 2 (dua) alasan penolakan atasnya oleh umat Islam. Pertama, RUU tersebut dinilai bertentangan ajaran Islam (hukum Islam) seperti sahnya perkawinan, prinsip monogami dan perkawinan antaragama. Kedua, masalah kedudukan Peradilan Agama yang tidak disebutkan dalam RUU tersebut. Dalam RUU tersebut hanya menyebutkan "Pengadilan dalam lingkup Peradilan Umum, hak pengadilan dan pengadilan." Disinyalir hal ini terjadi karena Departeman Agama tidak dilibatkan dalam peyusunan RUU tersebut. ${ }^{23}$

Dinamika ${ }^{24}$ dalam pembahasan RUU Perkawinan tersebut berakhir dengan kompromi antara Pemerintah dengan perwakilan umat Islam. RUU yang semula berjumlah 73 pasal kemudian disempitkan menjadi 67 pasal. ${ }^{25}$ Maka pada tanggal 22 Desember 1973 dalam sidang DPR akhirnya RUU tersebut diterima dan disahkan oleh semua fraksi.

\footnotetext{
${ }^{21}$ Nalom Kurniawan, "Keterwakilan Perempuan di Dewan Perwakilan Rakyat Pasca Putusan Mahkamah Konstitusi Nomor 22-24/PUU-VI/2008”, dalam Jurnal Konstitusi, Vol. 11 No. 4, Desember 2014, h. 714-736.

${ }^{22}$ Chusnul Mar'iyah, "Membaca Ulang Politik: Pendekatan Feminisme dan Metodologi Penelitian", Afirmasi; Jurnal Pengembangan Pemikiran Feminis, Vol. 02, Januari 2013, h. 239.

${ }^{23}$ Azyumardi Azra, dkk, Menteri-Menteri Agama RI; Biografi Sosial-Politik (Jakarta: INIS-PPIM, 1998), h. 5.

${ }^{24}$ Suasana pembahasan dan dinamika RUU Perkawinan dapat dibaca melalui beberapa sumber, di antaranya: Abdul Aziz Thaba, Islam dan Negara dalam Politik Orde Baru (1966-1994), (Jakarta: Gema Insani Press, 1996); Majalah Tempo, 8 September, 6 Oktober, 13 Oktober 1973, Panji Masyarakat, No. 252, thn XX, 1 Agustus 1978. Risalah Resmi Rapat Pleno Terbuka ke-7 Pembahasan RUU Perkawinan, selasa, 18 Agustus 1973 (penerbit DPR RI).

25Tentang penyempitan dari 73 menjadi 67 terdapat pasal yang dihapus dan adapula yang dimasukkan pada item pasal yang sesuai. Pasal 14 mengenai Tata Cara Gugatan Perkawinan dan Pasal 62 mengenai Pengangkatan Anak merupakan bagian dari pasal-pasal yang dihapus.
} 
Dengan disahkannya Undang-Undang No. 1 Tahun 1974 tentang Perkawinan dan dikeluarkannya Peraturan Pemerintah No. 9 Tahun 1975 tentang Pelaksanaan Undang-Undang No.1 Tahun 1974 tentang Perkawinan, maka berlakulah peraturan tersebut secara nasional untuk masyarakat Indonesia, yang tidak mengikat dalam penghapusan atas ketentuan peraturan perkawinan yang ada, seperti hukum Islam. Hal ini yang disampaikan Hazairin ${ }^{26}$ dan Soemiyati27 bahwa hukum perkawinan Islam masih dapat berlaku, sebagaimana diatur dalam Pasal 66 dan Pasal 2 ayat 1 UU No.1 Tahun 1974 tentang Perkawinan:

“... dan peraturan-peraturan lain yang mengatur tentang perkawinan sejauh telah diatur dalam Undang-undang ini, dinyatakan tidak berlaku".

Namun demikian,

“.. bahwa perkawinan adalah sah apabila dilakukan menurut masing-masing agamanya dan kepercayaannya.

Seiring dinamika yang berkembang, dan dalam "menjaga hubungan" dengan kepentingan-kepentingan umat Islam, kemudian lahirlah UndangUndang No. 7 Tahun 1987 tentang Peradilan Agama, serta melalui Instruksi Presiden No.1 Tahun 1991 serta berdasarkan SK. Menteri Agama No. 154 Tahun 1991 diterapkanlah Kompilasi Hukum Islam (KHI). ${ }^{28} \mathrm{KHI}$ ini terdiri dari Buku I tentang Perkawinan, Buku II tentang Kewarisan, Buku III tentang Perwakafan.

\section{Invertilitas sebagai Alasan Poligami: Refleksi Ketidakadilan Gender}

Secara kodrati struktur organ biologis manusia baik laki-laki maupun perempuan relatif berbeda, khususnya yang terkait dengan reproduksi, baik sebagai laki-laki atau perempuan. Dalam kondisi normal keduanya dapat saling melengkapi dengan dibuahi dan membuahi. Akan tetapi dalam kondisi tidak normal keduanya menjadi rentan dengan risiko yang sama; yaitu terjadi

\footnotetext{
26Sudarsono, Hukum Perkawinan Nasional (Jakarta: Rineka Cipta, 2010), h.10.

${ }^{27}$ Soemiyati, Hukum Perkawinan Islam dan Undang-undang Perkawinan (Yogyakarta: Liberty, 2007), h. 2-3.

${ }^{28}$ Amir Nuruddin dan Azhari Akmal Tarigan, Hukum Perdata Islam di Indonesia; Studi Kritis Perkembangan Hukum Islam dari Fikih, UU No.1/1974 sampai KHI (Jakarta: Kencana, 2004), h. 27.
} 
invertilitas (kemandulan). Invertilitas bukan hanya dapat dialami oleh perempuan saja, akan tetapi juga dapat dialami oleh laki-laki.

Dengan demikian, berangkat dari kekurangan yang ada pada masingmasing pasangan perkawinan, terdapat ketentuan hukum yang tidak menguntungkan yang ditimpakan kepada salah satu pihak jika invertilitas yang dialami istri menjadi alasan poligami. Sementara itu, tidak berakibat hukum apapun jika kondisi yang sama dialami oleh suami. Pasal 4 Ayat 2 UndangUndang No. 1 Tahun 1974 tentang Perkawinan menyebutkan:

"Pengadilan dimaksud pada ayat (1) pasal ini hanya memberikan izin kepada seorang suami yang akan beristri lebih dari seorang apabila:

(a) istri tidak dapat menjalankan kewajibannya sebagai istri;

(b) istri mendapat cacat badan atau penyakit yang tidak dapat disembuhkan;

(c) istri tidak dapat melahirkan keturunan."

Mencermati ketentuan perundang-undangan perkawinan di Indonesia tersebut, muncul pertanyaan tentang keadilan dan kemanusiaan dalam perspektif gender. Adilkah dan berkemanusiaankah ketentuan yang memenangkan salah satu pihak tersebut? Bagaimana cerminan amanat pada Pasal 1 (yang mempertimbangkan aspek lahir dan batin sekaligus) jika perkawinan karena sebab fisik semata dapat merubah ketentuan hukum yang mendasar? Sementara perkawinan telah didefinisikan adalah bukan ikatan lahir (fisik) semata tapi juga ikatan batin. Bukankan poligami yang diizinkan karena cacat fisik seorang istri akan merusak ikatan batin yang bersangkutan (terutama yang menjadi korban), sementara seorang istri tersebut sedang tidak berdaya (tertindas) karena cacat fisik yang disandangnya? Bagaimana jika yang mengalami cacat atau kekurangan fisik itu adalah seorang suami, dapatkah putusan hukum pengadilan akan memutuskan hal yang sama atau sepadannya?

Penindasan yang dilegalkan secara hukum dalam bentuk "poligami sepihak" merupakan pintu masuk untuk menghilangkan makna dan marwah perkawinan itu sendiri. Dan ketentuan semacam ini berpotensi menciptakan kerancuan pemaknaan atas misi penciptaan keluarga bahagia berdasarkan Ketuhanan Yang Maha Esa. Apa yang dinyatakan Pasal 4 Ayat 2 UU No.1 Tahun 1974 ini terkesan memahami perkawinan dari satu sudut pandang saja; yakni 
kepentingan laki-laki. Perkawinan yang merupakan peristiwa yang sifatnya sangat privat sekalipun ternyata masih didominasi laki-laki; alih-alih terjadi kesetaraan gender antara laki-laki dan perempuan dalam ranah publik. Nilainilai kemanusiaan, keadilan, kebijaksanaan, dan ketuhanan dalam sila-sila Pancasila rasanya juga sulit ditemukan dalam pencermatan atas pasal tersebut.

Memperebutkan keadilan dan kemanusiaan memang merupakan isu yang sensitif dan sarat polemik. Hal ini akan semakin menegang jika pandangan yang digunakannya berbasis argumentasi teks keagamaan yang regresif serta jumud. Ketidakadilan gender semacam ini seolah tersimpan dalam ruang bawah sadar kolektif yang tidak bisa diungkit-ungkit lagi. Mempertanyakannya tidak jarang dianggap telah keluar dari common sense dari kehidupan berbangsa, benegara dan beragama. Itu sebabnya, isu semacam ini kerapkali tersembunyi dan terselubung dalam perhatian banyak kalangan, tidak terkecuali dalam ranah putusan hukum sekalipun. Padahal dalam kenyataannya potensi kemampuan dan ketidakmampuan bereproduksi seseorang, baik yang berjenis kelamin laki-laki maupun perempuan, adalah sama. Keduaduanya memiliki peluang yang sama untuk bisa memiliki keturunan atau tidak. Harapan mendapatkan keturunan dalam perkawinan adalah kewajaran, karena itu fitrah, akan tetapi persoalan ketidakmampuan untuk "membuahi" ataupun "dibuahi" menjadi tidak wajar jika hanya ditimpakan kepada perempuan-yang dalam konteks perkawinan adalah sebagai istri.

Dalam sidang uji materiil UU No. 1 Tahun 1974 tentang Perkawinan di Mahkamah Konstitusi, Pemerintah yang diwakili oleh Dirjen Bimas Islam Departemen Agama, Nasaruddin Umar, ${ }^{29}$ menyajikan data yang menunjukkan poligami justru menjadi salah satu penyebab utama perceraian. Menurutnya, catatan dari Pengadilan Agama di seluruh Indonesia pada 2004, terjadi 813 perceraian akibat poligami. Pada 2005 angka itu naik menjadi 879 dan pada 2006 melonjak menjadi 983.

"Data-data ini menunjukkan poligami justru melanggengkan dan menyebabkan perceraian. Poligami jadi penyebab utama bubarnya suatu perkawinan,... juga menyebabkan terlantarnya perempuan dan anak-anak".

\footnotetext{
${ }^{29}$ Nasarudin Umar, "Poligami Justru Jadi Penyebab Perceraian", dalam www. kemenag.go.id/index.php?a=berita\&id=78883.
}

AL-AHKAM

p-ISSN: 0854-4603; e-ISSN: 2502-3209

Volume 27, Nomor 2, Oktober 2017 || 205 
Syarat izin dari istri yang harus diperoleh seorang suami untuk berpoligami, seperti yang diatur dalam Undang-undang Perkawinan, dimaksudkan untuk menghindari dampak buruk poligami. Hal ini mengingat UndangUndang Perkawinan sama sekali tidak menutup pintu untuk berpoligami, melainkan hanya mengatur syarat-syaratnya. Dalam praktiknya, Pengadilan Agama cukup banyak mengeluarkan izin berpoligami. Fenomena hukum semacam ini menunjukkan bahwa Undang-Undang Perkawinan masih membuka jalan bagi seorang pria untuk memiliki istri lebih dari satu sepanjang memenuhi syarat yang telah ditentukan.

Data menunjukan bahwa pada 2004, Pengadilan Agama seluruh Indonesia mengeluarkan 800 izin poligami dari 1016 permohonan. Pada 2005 terdapat 803 izin dari 989 permohonan, dan pada 2006 terdapat 776 izin dari 1148 permohonan. ${ }^{30}$

Dari data tersebut, sekiranya perlu dianalisis bagaimana peran seorang hakim, terutama di Pengadilan Agama, dalam merespon aturan hukum perkawinan di Indonesia jika dikaitkan dengan isu kesetaraan gender. Hal ini mengingat secara normatif segala keputusan hukum tentang perkawinan di Pengadilan Agama selalu mengacu pada UU No 1 Tahun 1974 dan Kompilasi Hukum Islam (KHI) sebagai aturan pendukungnya. Bagaimana pula hubungan antara pemahaman hakim Pengadilan Agama tentang gender dan aturan hukum perkawinan. Pertanyaan inilah yang pernah menjadi basis penelitian para pemerhati isu keadilan gender di Indonesia. Di antaranya adalah Syarafuddin yang melakukan penelitian tentang persoalan tersebut di Pengadilan Agama Surakarta. ${ }^{31}$

Menurut Syarafuddin, respon hakim Pengadilan Agama terkait isu kesetaraan gender dalam UU Perkawinan dan KHI memiliki dua bentuk. Pertama, hakim Pengadilan Agama memiliki kecenderungan normatif dalam persepsinya yang berhubungan dengan kedudukan suami-istri dalam rumah tangga yang membawa konsekuensi hukum (yuridis). Kelompok kategori ini memahami

\footnotetext{
${ }^{30}$ Nasarudin Umar, "Poligami Justru Jadi Penyebab Perceraian", dalam www.kemenag.go. id/index.php?a=berita\&id=78883.

${ }^{31}$ Syarafuddin, "Kesetaraan Gender dalam Undang-Undang No.1 Tahun 1974 dan Kompilasi Hukum Islam; Respon Hakim Pengadilan Agama Surakarta Tahun 2013”, Jurnal SUHUF, Vol. 26, No. 1, Mei 2014, h. 21-37.
} 
dengan mendudukkan laki-laki sebagai kepala keluarga yang memberi nafkah bagi keluarga justru memberikan kepastian hukum dalam konstruksi gender, di mana laki-laki dan perempuan dapat saling membagi perannya. Dari sini tampak peran hukum yang memberi kepastian di tengah perubahan sosial. Kedua, hakim Pengadilan Agama yang secara umum mempersepsikan peran yang cenderung lebih elastis antara suami dan istri dalam kehidupan keluarga. Mereka tidak membagi peran antara suami-istri secara kaku pada hal-hal yang berkaitan dengan urusan nafkah, rumah tangga, dan kewajiban mendidik anak. Sebagian besar berpendapat bahwa kerjasama di antara keduanya justru lebih baik, bukan atas dasar pembagian peran yang ketat. ${ }^{32}$

Sejatinya, tujuan perkawinan menurut Islam adalah agar seseorang mendapatkan ketenangan. Apabila dengan pernikahan seseorang menginginkan di luar maksud tersebut, maka sudah tidak lagi sesuai dengan tujuan perkawinan. Jika Undang-Undang Perkawinan membuka jalan bagi poligami dengan syarat yang ketat, maka sudah sejalan dengan ajaran Islam. Namun keadilan hukum juga perlu dijalankan di atas jalur kebijaksanaan, empati dan kepekaan terhadap sisi-sisi kemanusiaan. Kondisi invertilitas dan cacat fisik yang tidak diinginkan akan menjadi pemicu rasa ketidakadilan jika dijadikan sebab putusan pengadilan yang sepihak. Ibarat kata pepatah, putusan pengadilan bagi seorang istri karena kondisi tersebut bagaikan "sudah jatuh tertimpa tangga". Aspek ketenangan yang menjadi tujuan utama perkawinan menjadi tersisihkan.

Poligami memang tidak dilarang dalam Islam. Namun demikian, poligami hanya boleh dilakukan apabila seorang pria bukan hanya mampu untuk menghidupi istri-istrinya, tapi juga dapat berlaku adil dalam segala perlakuan dalam pandangan istri-istrinya.

Kajian mengenai perkawinan Islam semestinya juga dilakukan dengan pendekatan gender. Ide ini pernah dikemukakan oleh Musyafa'ah ${ }^{33}$ yang menyorot secara kritis pola pembelajaran hukum perkawinan Islam dalam dunia pendidikan di Indonesia. Tidak dapat dipungkiri bahwa pembelajaran

\footnotetext{
32Syarafuddin, “Kesetaraan Gender dalam Undang-Undang No.1 Tahun 1974...., h. 34.

${ }^{33}$ Nur Lailatul Musyafa'ah, "Studi Hukum Perkawinan Islam di Indonesia Perspektif Gender", AlHukama; The Indonesian Journal of Islamic Family Law, Vol. 4 No. 2, Desember 2014, h. 410-429.
} 
hukum perkawinan Islam - yang merupakan mata kuliah yang wajib dipelajari di Fakultas Syariah- masih sebatas dan cenderung merujuk kepada pendapat-pendapat hukum mazhab klasik, Undang-Undang Nomor 1 Tahun 1974 tentang Perkawinan, dan Kompilasi Hukum Islam. Seiring perkembangan zaman dan meningkatnya dinamika kehidupan masyarakat serta pembaruan pemikiran hukum Islam, materi hukum perkawinan Islam perlu dikaji lebih mendalam dengan berbagai pendekatan; salah satunya dengan pendekatan gender. Hal ini penting dilakukan karena telah banyak karya dari para pemikir Muslim kontemporer yang merumuskan adanya pembaruan dalam hukum perkawinan Islam demi tercapainya kesetaraan gender dalam perkawinan yang sesuai dengan perkembangan zaman. Misalnya, kajian diperdalam dan diperluas dengan melakukan reinterpretasi teks al-Qur'an dan Hadis tentang Hukum Perkawinan dengan pendekatan kontekstualisasi relasi gender. Diharapkan adanya pembelajaran hukum perkawinan Islam dengan pendekatan gender, konsepsi pemikiran hukum perkawinan dapat dibangun secara kritis, tidak kaku, serta terbebas dari seksisme pemikiran.

Banyak kalangan pemerhati menilai bahwa Kompilasi Hukum Islam, yang merupakan hukum "turunan" dari Undang-Undang No.1 Tahun 1974 tentang Perkawinan, juga memuat ambiguitas hukum dalam ketentuan-ketentuannya tentang perempuan. Diantaranya adalah analisis gender Solikul Hadi yang mengemukakan ambivalensi pada aturan pemerintah tentang perkawinan. ${ }^{34}$ Di satu sisi pemerintah mengakui legal capacity kaum perempuan, namun di sisi lain justru mengukuhkan pembagian peranan berdasarkan jenis kelamin (sex roles) secara kaku serta menguatkan stereotype terhadap perempuan. Karena istri adalah seorang yang berjenis kelamin perempuan, maka perannya dibatasi pada sektor domestik. Dan karena seorang suami berjenis kelamin laki-laki, maka perannya adalah di sektor publik.

Dari paparan di atas dapat ditegaskan lagi bahwa KHI dan UU Perkawinan dalam merumuskan peran, kedudukan, dan hak-hak perempuan sangat memperlihatkan konsep keluarga patriarki. Perempuan diposisikan subordinat terhadap posisi laki-laki. Dampak sosial dari domestifikasi perempuan tersebut menyebabkan perempuan tergeser dari penguasaan sumber daya ekonomi,

${ }^{34}$ Solikul Hadi, "Bias Gender dalam Konstruksi Hukum Islam di Indonesia”, Jurnal Palastren, Vol. 7, No. 1, Juni 2014, h. 25-44. 
sosial dan politik. Secara ekonomis ia tergantung pada suaminya, sedang peran suami sebagai pencari nafkah lebih memungkinkannya untuk memiliki akses sumber daya sosial, politik dan ekonomi. Karenanya, dengan memperhatikan dampak sosial dan argumentasi-argumentasi di atas, sebagai upaya menegakkan keadilan dan persamaan hak sebagaimana yang diajarkan oleh Islam, maka tatanan relasi gender dalam KHI yang merumuskan peran, kedudukan dan hakhak perempuan yang berbeda dengan laki-laki, perlu direkonstruksi.

Rekonstruksi yang dimaksud terutama perlu dilakukan dalam pemikiran keagamaan. Hal ini mengingat fakta pemahaman keagamaan yang begitu menentukan arah pemikiran dalam pelbagai sektor kehidupan lainnya. Lebihlebih pemikiran keagamaan Islam yang secara mayoritas mendominasi kehidupan berbangsa dan bernegara di Indonesia.

Disadari atau tidak, kecenderungan umum dalam pemaknaan teks agama didominasi oleh pola pemaknaan secara literal dan karenanya mengabaikan pemaknaan substansial. Kebanyakan teks dimaknai menurut makna lahiriahnya saja. Padahal, di dalam makna lahiriah tersebut tersembunyi pesan-pesan fundamental yang ingin ditegakkan. Pesan fundamental agama yang berupa keadilan dan kemaslahatan merupakan nilai-nilai moral universal yang perlu ditegakkan. Pesan-pesan inilah yang seharusnya menjadi perhatian utama ketika memaknai kembali teks-teks keagamaan untuk diaplikasikan dalam menyikapi konteks-konteks yang sedang terjadi; bukan sepenuhnya berhenti pada makna literalnya belaka. ${ }^{35}$

Dalam masalah pemukulan suami terhadap istri, misalnya, yang secara lahiriah disebutkan oleh teks al-Qur'an surat al-Nisā' ayat 34, pastilah mengandung makna substansialnya. Pemukulan, dalam konteks ayat tersebut, adalah satu bentuk dan cara memberikan pendidikan terhadap istri yang "tidak taat" (nushūz) yang dalam konteks sosial waktu itu dibenarkan, karena suami diposisikan sebagai qawwām atas istri. Cara tersebut dimaksudkan guna menyelesaikan ketidakharmonisan antara mereka karena ia merupakan cara dan dalam konteks tertentu. Oleh karena itu, cara tersebut bukanlah satusatunya cara dan dapat saja berubah dalam konteks yang lain. ${ }^{36}$

\footnotetext{
35Jonkenedi, "Rekonstruksi Kritis Pemikiran Gender dalam Islam", YINYANG; Jurnal Studi Gender \& Anak, Vol. 4 No. 1, Januari-Juni 2009, h. 71-84.

36Ibid., h. 79.
} 
Dalam masyarakat yang kesetaraan, keadilan, dan penghargaan terhadap hak-hak asasi manusia dijunjung tinggi, maka dalam rangka menyelesaikan suatu persoalan rumah tangga sekalipun, dilakukan melalui cara-cara yang dialogis-demokratis dan menghargai martabat manusia. Ini adalah pesanpesan yang tersembunyi di balik makna lahiriah teks agama tersebut dan merupakan substansi pandangan Islam.

Demikian juga persoalan poligami yang dinyatakan dalam al-Qur'an surat al-Nisa' ayat 3. Teks agama ini sering dimaknai bukan hanya secara lahiriyah, tapi bahkan dimaknai secara sepotong-sepotong dengan memenggal dan mengambil kalimat perintahnya saja (fankihü- فانكحو) tanpa memperhatikan kalimat persyaratan sebelumnya; alih-alih dimaknai secara kontekstual dan pendekatan sosio-historisnya. Padahal, semangat dari teks agama tersebut menegaskan agar perhatian kepada anak yatim perlu lebih diintensifkan lagi dengan seadil-adilnya. Sehingga jelas sekali bahwa diperbolehkannya poligami dalam Islam adalah untuk menjunjung tinggi keadilan, bukan sebaliknya.

Untuk memahami lebih kritis atas persoalan pemahaman keagamaan ini, mutlak memerlukan studi atau analisis tentang sejarah sosial, politik dan ekonomi, tempat ayat-ayat tersebut muncul. Ilmu-ilmu al-Qur'an masih menyisakan teori-teori ini melalui apa yang dikenal dengan istilah "asbāb alnuzūl", dan lebih dari itu, adalah apa yang diistilahkan al-Shāțibi dengan "muqtadayāt al-ahwwāl" (konteks sosial) dan "al-'ādat" (tradisi-tradisi) Arab.37

\section{Kesimpulan}

Hasil yang ditemukan dari kajian dalam artikel ini dapat disimpulkan ke dalam tiga pernyataan pokok. Pertama, bahwa UU No. 1 Tahun 1974 beserta perundang-undangan turunannya seperti $\mathrm{KHI}$, masih jauh dari nilai-nilai Pancasila dan misi utama hukum; yaitu nilai keadilan dan kemanusiaan. Kedua, konfigurasi politik dalam produksi UU Perkawinan dan pemahaman teks agama yang "hitam-putih" adalah kontributor terciptanya ketidakadilan. Ketiga, salah satu tujuan hukum adalah keadilan, maka bentuk-bentuk diskriminasi harus dihapuskan. Itu sebabnya, pasal 4 UU No. 1 Tahun 1974

37al-Shātịī, al-Muwāfaqātfí Ușil al-Sharīah (Kairo: Maktabah Tijariyah Kubra), h. 347-351. 
selayaknya dihapus atau tidak berlaku lagi, sehingga konsekuensinya adalah asas monogami bersifat mutlak.[a]

\section{DAFTAR PUSTAKA}

Ali, Zainuddin, Sosiologi Hukum, Jakarta: Media Grafika, 2017.

Atmasasmita, Romli, Teori Hukum Integratif Rekonstruksi terhadap Teori Hukum Pembangunan dan Teori Hukum Progresif, Yogyakarta: Genta Publishing, 2014.

Azra, Azyumardi, dkk, Menteri-menteri Agama RI: Biografi Sosial-Politik, Jakarta: INIS-PPIM, 1998.

Fakih, Mansour, Analisis Gender dan Trasformasi Sosial, Yogyakarta: Pustaka Pelajar, 2013.

Hadi, Solikul, "Bias Gender dalam Konstruksi Hukum Islam di Indonesia", dalam Jurnal Palastren, Vol. 7 No. 1, Juni 2014.

Jonkenedi, "Rekonstruksi Kritis Pemikiran Gender dalam Islam", YINYANG; Jurnal Studi Gender \& Anak, Vol.4 No.1, Januari-Juni 2009.

Kurniawan, Nalom, "Keterwakilan Perempuan di Dewan Perwakilan Rakyat Pasca Putusan Mahkamah Konstitusi Nomor 22-24/PUU-VI/2008", Jurnal Konstitusi, Vol.11 No.4, Desember 2014.

Lubis, Akhyar Yusuf, Pemikiran Kritis Kontemporer; Dari Teori Kritis Hingga Multikulturalisme, Jakarta: Rajawali Press, 2015.

Marzuki, Peter Mahmud, Penelitian Hukum, Jakarta: Kencana, 2014.

Mar'iyah, Chusnul, "Membaca Ulang Politik: Pendekatan Feminisme dan Metodologi Penelitian", Afirmasi; Jurnal Pengembangan Pemikiran Feminis, Vol. 02, Januari 2013.

MD, Mahfud, Politik Hukum di Indonesia, Jakarta: Raja Grafindo, 2009.

Meliala, Djaja S., Hukum Perdata dalam Perspektif BW, Bandung: Nuansa Aulia, 2013.

Mertokusumo, Sudikno, Mengenal Hukum, Yogyakarta: Universitas Atmajaya, 2010.

Murhaini, Suriansyah, Hukum dan Sejarah Hukum: Pengantar Singkat Memahami Sejarah Hukum Indonesia, Yogyakarta: LaksBang Pressindo, 2016.

Mustafied (ed.), Kontekstualisasi Turast; Telaah Regresif dan Progresif, Surabaya: De-aly, 2009. 
Nur Kholis, Jumaiyah, Wahidullah

Musyafa'ah, Nur Lailatul, "Studi Hukum Perkawinan Islam di Indonesia Perspektif Gender", Al-Hukama; The Indonesian Journal of Islamic Family Law, Vol 4 No.2, Desember 2014.

Nuruddin, Amir dan Azhari Akmal Tarigan, Hukum Perdata Islam di Indonesia; Studi Kritis Perkembangan Hukum Islam dari Fikih, UU No.1/1974 sampai KHI, Jakarta: Kencana, 2004.

Sairin, Weinata dan J.M Pattiasina, Pelaksanaan Undang-Undang Perkawinan dalam Perspektif Kristen, Jakarta: Gunung Mulia, 1996.

Soemiyati, Hukum Perkawinan Islam dan Undang-undang Perkawinan, Yogyakarta: Liberty, 2007.

Soekanto, Soerjono, Pengantar Penelitian Hukum, Jakarta: UI press, 1986. Pokok-Pokok Sosiologi Hukum, Jakarta: Rajawali Press, 1987. dan Sri Mamudji, Penelitian Hukum Normatif Suatu Tinjauan Singkat, Jakarta: RajaGrafindo Persada, 2014.

Subekti, R., dan R.Tjitrosudibio, Kitab Undang-Undang Hukum Perdata Edisi Revisi Burgerlijk Wetboek, Jakarta: Pradnya Paramita, 1995.

Sudarsono, Hukum Perkawinan Nasional, Jakarta: Rineka Cipta, 2010.

Sumitro, Ronny Hanitiyo, Metodologi Penelitian Hukum dan Jurimetri, Jakarta: Ghalia Indonesia, 1994.

Sunggono, Bambang, Metodologi Penelitian Hukum; Suatu Pengantar, Jakarta: Raja Grafindo Persada, 1997.

Syarafuddin, "Kesetaraan Gender dalam Undang-Undang No.1 Tahun 1974 dan Kompilasi Hukum Islam; Respon Hakim Pengadilan Agama Surakarta Tahun 2013", Jurnal SUHUF, Vol. 26, No. 1, Mei 2014.

al-Shāțibi, al-Muwāfaqāt fi Ușūl al-Sharīah, Kairo: Maktabah Tijāriyah Kubrā, 2000.

Thaba, Abdul Aziz, Islam dan Negara dalam Politik Orde Baru (1966-1994), Jakarta: Gema Insani Press, 1996.

Umar, Nasarudin, Argumentasi Kesetaraan Gender Perspektif al-Qur'an, Jakarta: Paramadina, 1999.

"Poligami Justru Jadi Penyebab Perceraian", http://www.kemenag. go.id/index.php?a=berita\&id=78883

Warasih, Esmi, Pranata Hukum; Sebuah Telaah Sosiologis, Semarang: Suryadaru Utama, 2005. 